\title{
Adequacy of preventive measures, awareness, and attitude regarding the COVID-19 pandemic among university pharmacy students
}

\author{
Saba Tariq ${ }^{1}$ (D) , Sundus Tariq ${ }^{2}$ (D) Mukhtiar Baig ${ }^{3}$ (D), Saadia Shahzad Alam ${ }^{4}$ \\ ${ }^{1}$ Pharmacology, University Medical \& Dental College, Faisalabad, Pakistan \& University of Health Sciences, Lahore, Pakistan \\ ${ }^{2}$ Physiology, University Medical \& Dental College, Faisalabad, Pakistan \& University of Health Sciences, Lahore, Pakistan \\ ${ }^{3}$ Faculty of Medicine, Rabigh, King Abdulaziz University, Jeddah, Kingdom of Saudi Arabia \\ ${ }^{4}$ Pharmacology, Shaikh Khalifa Bin Zayed Al Nahyan Medical and Dental College, Lahore, Pakistan.
}

Keywords
Knowledge
Attitude
Preparedness
Pharmacy Students
Social Media
Correspondence
Saba Tariq
Pharmacology
University Medical \& Dental College
Faisalabad-38000
Pakistan
drsabatariq1@gmail.com

\section{Introduction}

The coronavirus disease 2019 (COVID-19) emerged initially in China and has since spread to more than 200 countries, and by 7th October 2020, there were 35,659,007 confirmed cases globally with 1,044,269 deaths (World Health Organization (WHO), 2020a). Because of this novel infection's indefinite nature, there has been a great deal of panic and misinformation about the infection itself, how it can spread, and the important precautionary measures that ought to be taken to forestall contamination.

\begin{abstract}
Introduction: The aim was to investigate the adequacy of preventive measures, awareness, and attitudes of pharmacy university students in the Punjab province, Pakistan, during the COVID-19 pandemic. Methods: This cross-sectional survey was designed at a private university in Faisalabad, Pakistan. The questionnaire was developed on Google forms and distributed to students of five universities in the Punjab province via WhatsApp groups. Results: The comparison of COVID-19 knowledge for specific questions showed that non-pharmacy students (NPS) had significantly better knowledge about the source of the virus $(p<0.001)$, while pharmacy students (PS) had better knowledge regarding COVID-19 treatment $(p=0.01)$. The PS's perception of the dangerousness and risk of contracting COVID-19 infection was better than NPS's perception ( $p=0.026 ; p=0.019$, respectively). The regression analysis revealed that the knowledge score was negatively associated with the female gender, and females were less likely to have a positive attitude. Conclusion: The authors' results suggest that PS had good knowledge, positive attitude, and preparedness towards COVID-19. However, there are still misconceptions and confusion about the disease.
\end{abstract}

Many countries' most important step was to implement a lockdown to reduce the spread of the virus (Mohamad \& Azlan, 2020). In Pakistan, the virus was spreading swiftly, and on 13th March 2020, the National Security Council (NSC) in Pakistan announced the closure of schools and universities, and on 21st March 2020, all international flights were also suspended. All provinces started lockdown in March 2020, and that two months-long imposed lockdown was lifted on 9th May 2020 (International Crisis Group, 2020). Different strategies 
were adopted by the government to combat the disease; one of the strategies is building a so-called tiger force consisting of Pakistani youth (Akram, 2020). A Corona Relief Tiger Force was constituted by the prime minister of Pakistan, comprised of Pakistan's youth in all provinces to support the police, civil servants, and health officials during the COVID-19 pandemic. Their duties range from ensuring that social distancing laws are enforced in mosques and government food stores to aiding the vulnerable in administering emergency cash payments. The lockdown restrictions were followed strictly throughout Pakistan. The disease was spreading exponentially, and the only way to combat the disease was to follow the Standard Operating Procedures (SOPs) provided by the government of Pakistan (Government of Pakistan, 2020).

The rapid spread of the disease in Pakistan (WHO, 2020a) and other Asian countries warn against premature relaxation in restrictions and suggest a lack of basic knowledge among the population (Ghadyani et al., 2020). The main burden of the disease lies with frontline healthcare workers (Shechter et al., 2020).

Several routes of COVID-19 transmission have been identified, such as through respiratory droplets of various sizes, interaction with infectious individuals, or contaminated surfaces and objects (WHO, 2020b). Aerosol transfer can also occur in crowded, poorly ventilated indoor environments where people speak, yell, or sing (WHO, 2020b). In COVID-19 outbreaks recorded in closed settings, such as nightclubs, restaurants, certain workplaces, and places of worship, aerosol transmission can play a role (WHO, 2020b). The treatment of COVID-19 is only symptomatic, and vaccination for the disease is under trial (Cohen, 2020; Lurie et al., 2020; Shoenfeld, 2020). This episode of the COVID-19 pandemic has affected all stakeholders, and university students are directly and indirectly affected.

The pandemic has explicitly exposed the absence of planning and preparation for such emergency educational circumstances (Nantwi \& Boateng, 2020). Digital learning on educational networks is an entirely new way to communicate and connect with university students. Abrupt changes from conventional face-to-face to completely online teaching and learning induced anxiety and uncertainty in students, negatively influencing students' grades (Chandasiri, 2020). Students faced further difficulties because they could not access academic libraries and failed to complete the assignments adequately (Sahu, 2020). Notably, the move to online mode and the lack of laptops and internet connectivity at students' homes, as well as the challenge of teaching practical and laboratory courses posed concerns (Sahu, 2020). Pharmacy students (PS) are an essential part of the healthcare team, and it is important to assess their knowledge regarding COVID-19. Therefore, this study's objective was to explore the adequacy of PS's preventive measures, awareness, and attitudes during this pandemic and compare them to that of non-pharmacy students (NPS). This information will help policymakers and governments to design awareness campaigns more effectively to combat COVID-19 and similar pandemics in the future.

\section{Methods}

This cross-sectional survey was designed at The University of Faisalabad (TUF), Pakistan. The researchers developed the questionnaire with the help of an already published study (Srichan et al., 2020). The researchers tested the questionnaire in a pilot study to check the questions' construct validity and reliability, and Cronbach's alpha of greater than 0.7 was considered valid for all the questions. Ethical permission for the study was granted by the ethical review committee of TUF, Pakistan.

The questionnaire had two important components. The first component measured all students' demographic characteristics, and the second component measured the acceptability of preventive measures, knowledge, and attitudes towards the COVID-19 pandemic. The questionnaire was distributed online to students of five universities in the Punjab province who have a pharmacy faculty. The questionnaire consisted of fourteen knowledge questions, five attitude assessment questions, and three practice-related questions. The questions' format assessing knowledge, attitudes, and preparedness was correct and incorrect, five-point Likert scale (from seriously dangerous to not dangerous) and three-point scale (nil, sometimes and every time). For calculating the knowledge score, one point was awarded for the correct answer and zero for an incorrect answer and $<50 \%$, $51-75 \%$, and $>75 \%$ scores were considered poor, moderate and good, respectively. For attitude, marking ranged from minus to plus (true answer +1 and false and not sure -1), and an individual's scores in plus indicated a positive attitude. In contrast, the negative attitude was indicated in minus (Baig et al., 2020). The objective of the study was explained to students through Google Classroom. The title page of the study had information about the participation, consent, and confidentiality of data. 
The survey was conducted from 1st May 2020 to 10th May 2020. The NPS were mainly from the departments of social sciences, engineering, nutrition, and optometry. The medical and dental students were excluded from the study because they were expected to better understand the preventive measures, have adequate awareness, and positive attitudes due to their clinical rotations and interactions with patients.

The data were analysed using the Social Sciences Statistical Package 24. The percentages and frequencies were calculated, and the chi-square test was employed to assess the statistically significant frequency difference. Linear and logistic regressions were used to identify predictors of the knowledge scores and positive attitudes.

\section{Results}

The study's response rate was $73 \%(810 / 1100)$. This study included 810 students (391 (48.27\%) PS, 419 (51.72\%) NPS). There were 121 (14.9\%) males and 689 (85.1\%) females.
Table I: Comparison of general demographic characteristics of all the students with COVID-19 knowledge score

\begin{tabular}{|c|c|c|c|c|c|}
\hline Variables & & $\begin{array}{l}\text { Poor } \\
\text { n (\%) }\end{array}$ & $\begin{array}{c}\text { Moderate } \\
\text { n (\%) }\end{array}$ & $\begin{array}{l}\text { Good } \\
n(\%)\end{array}$ & $\begin{array}{c}p- \\
\text { value }\end{array}$ \\
\hline \multirow[t]{2}{*}{ Gender } & Male & $\begin{array}{c}61 \\
(50.4)\end{array}$ & $\begin{array}{c}57 \\
(47.1)\end{array}$ & $\begin{array}{c}3 \\
(2.5)\end{array}$ & 0.107 \\
\hline & Female & $\begin{array}{c}416 \\
(60.4)\end{array}$ & $\begin{array}{l}255 \\
(37)\end{array}$ & $\begin{array}{c}18 \\
(2.6)\end{array}$ & \\
\hline \multirow[t]{3}{*}{ Age (years) } & $<21$ & $\begin{array}{c}216 \\
(60.7)\end{array}$ & $\begin{array}{c}162 \\
(37.7)\end{array}$ & $\begin{array}{c}7 \\
(1.6)\end{array}$ & 0.081 \\
\hline & $21-25$ & $\begin{array}{l}210 \\
(58)\end{array}$ & $\begin{array}{c}139 \\
(38.4)\end{array}$ & $\begin{array}{c}13 \\
(3.6)\end{array}$ & \\
\hline & $>25$ & $\begin{array}{c}6 \\
(33.3)\end{array}$ & $\begin{array}{c}11 \\
(61.1)\end{array}$ & $\begin{array}{c}1 \\
(5.6)\end{array}$ & \\
\hline \multirow[t]{2}{*}{$\begin{array}{l}\text { Marital } \\
\text { status }\end{array}$} & Married & $\begin{array}{c}19 \\
(59.4)\end{array}$ & $\begin{array}{c}10 \\
(31.3)\end{array}$ & $\begin{array}{c}3 \\
(9.4)\end{array}$ & 0.041 \\
\hline & Unmarried & $\begin{array}{c}458 \\
(58.9)\end{array}$ & $\begin{array}{c}302 \\
(38.8)\end{array}$ & $\begin{array}{c}18 \\
(2.3)\end{array}$ & \\
\hline \multirow[t]{2}{*}{ Students } & Pharmacy & $\begin{array}{c}233 \\
(59.6)\end{array}$ & $\begin{array}{c}151 \\
(38.6)\end{array}$ & $\begin{array}{c}7 \\
(1.8)\end{array}$ & 0.379 \\
\hline & Non-Pharmacy & $\begin{array}{c}244 \\
(58.2)\end{array}$ & $\begin{array}{c}161 \\
(38.4)\end{array}$ & $\begin{array}{c}14 \\
(3.3)\end{array}$ & \\
\hline \multirow{3}{*}{$\begin{array}{l}\text { Number of } \\
\text { family } \\
\text { members }\end{array}$} & $1-3$ & $\begin{array}{c}27 \\
(50.9)\end{array}$ & $\begin{array}{c}25 \\
(47.2)\end{array}$ & $\begin{array}{c}1 \\
(1.9)\end{array}$ & 0.690 \\
\hline & $4-6$ & $\begin{array}{c}299 \\
(58.7)\end{array}$ & $\begin{array}{c}197 \\
(38.7)\end{array}$ & $\begin{array}{c}13 \\
(2.6)\end{array}$ & \\
\hline & $>7$ & $\begin{array}{c}151 \\
(60.9)\end{array}$ & $\begin{array}{c}90 \\
(36.3)\end{array}$ & $\begin{array}{c}7 \\
(2.8)\end{array}$ & \\
\hline
\end{tabular}

Table II: Comparison of COVID-19 knowledge between pharmacy and non-pharmacy students

\begin{tabular}{|c|c|c|c|c|}
\hline Variables & Response & $\begin{array}{c}\text { Pharmacy } \\
\text { Students N (\%) }\end{array}$ & $\begin{array}{l}\text { Non-Pharmacy } \\
\text { Students N (\%) }\end{array}$ & $\begin{array}{c}p- \\
\text { value }\end{array}$ \\
\hline \multirow[t]{2}{*}{ Is coronavirus contagious? } & Incorrect & $41(10.5)$ & $64(15.3)$ & 0.027 \\
\hline & Correct & $350(89.5)$ & $355(84.7)$ & \\
\hline \multirow{2}{*}{$\begin{array}{l}\text { Do you think having a prior health condition, such as heart disease or diabetes, could raise } \\
\text { the risk of getting coronavirus? }\end{array}$} & Incorrect & $171(43.7)$ & $190(45.3)$ & 0.348 \\
\hline & Correct & $220(56.3)$ & $229(54.7)$ & \\
\hline \multirow[t]{2}{*}{ What is the source of the coronavirus? } & Incorrect & $335(85.7)$ & $317(75.7)$ & $<0.001$ \\
\hline & Correct & $56(14.3)$ & $102(24.3)$ & \\
\hline \multirow[t]{2}{*}{ How does the coronavirus spread? } & Incorrect & $34(8.7)$ & $45(10.7)$ & 0.195 \\
\hline & Correct & $357(91.3)$ & $374(89.3)$ & \\
\hline \multirow[t]{2}{*}{ How would you describe coronavirus treatment? } & Incorrect & $179(45.8)$ & $227(54.2)$ & 0.010 \\
\hline & Correct & $212(54.2)$ & $192(45.8)$ & \\
\hline \multirow[t]{2}{*}{ Do you think the corona virus infection can be treated at home? } & Incorrect & $286(73.1)$ & $307(73.3)$ & 0.516 \\
\hline & Correct & $105(26.9)$ & $112(26.7)$ & \\
\hline \multirow[t]{2}{*}{ Do you think health education can help to prevent the disease? } & Incorrect & $12(3.1)$ & $11(2.6)$ & 0.433 \\
\hline & Correct & 379 (96.9) & $408(97.4)$ & \\
\hline \multirow[t]{2}{*}{ Are children also at risk of coronavirus infection? } & Incorrect & $32(8.2)$ & $35(8.4)$ & 0.517 \\
\hline & Correct & $359(91.8)$ & $384(91.6)$ & \\
\hline \multirow[t]{2}{*}{ Can the novel coronavirus be passed on through food? } & Incorrect & $304(77.7)$ & $331(79)$ & 0.365 \\
\hline & Correct & $87(22.3)$ & $88(21)$ & \\
\hline \multirow[t]{2}{*}{ What should be the safety levels of lab testing for corona virus? } & Incorrect & $351(89.8)$ & $362(86.4)$ & 0.085 \\
\hline & Correct & $40(10.2)$ & $57(13.6)$ & \\
\hline \multirow[t]{2}{*}{ Can a person infected with coronavirus recover completely and be no more infectious? } & Incorrect & $156(39.9)$ & $171(40.8)$ & 0.423 \\
\hline & Correct & $235(60.1)$ & $248(59.2)$ & \\
\hline \multirow{2}{*}{$\begin{array}{l}\text { How long does the coronavirus survive over porous surfaces (like paper, untreated wood, } \\
\text { cardboard, sponge and fabric) }\end{array}$} & Incorrect & $315(80.6)$ & $319(76.1)$ & 0.074 \\
\hline & Correct & $76(19.4)$ & $100(23.9)$ & \\
\hline \multirow[t]{2}{*}{ What type of mask should one wear to protect against the coronavirus? } & Incorrect & $212(54.2)$ & $249(59.4)$ & 0.077 \\
\hline & Correct & $179(45.8)$ & $170(40.6)$ & \\
\hline \multirow[t]{2}{*}{ Should the coronavirus outbreak concern you about your pets or other animals? } & Incorrect & $276(70.6)$ & $286(68.3)$ & 0.260 \\
\hline & Correct & $115(29.4)$ & $133(31.7)$ & \\
\hline
\end{tabular}


Table III: Comparison of COVID-19 perception of various attitudes among pharmacy and non-pharmacy students

\begin{tabular}{|c|c|c|c|c|}
\hline Variables & Response & $\begin{array}{c}\text { Pharmacy } \\
\text { students } \\
\text { N (\%) }\end{array}$ & $\begin{array}{c}\text { Non- } \\
\text { Pharmacy } \\
\text { Students } \\
\mathbf{N}(\%)\end{array}$ & $\begin{array}{c}p- \\
\text { value }\end{array}$ \\
\hline \multirow{5}{*}{$\begin{array}{l}\text { What is your } \\
\text { perception of the } \\
\text { dangerousness of } \\
\text { COVID-19? }\end{array}$} & Seriously dangerous & $277(70.8)$ & $257(61.2)$ & 0.026 \\
\hline & Very dangerous & $58(14.8)$ & $78(18.6)$ & \\
\hline & Dangerous & $44(11.3)$ & 71 (16.9) & \\
\hline & Like the common flu & $5(1.3)$ & $9(2.1)$ & \\
\hline & Not dangerous & $7(1.8)$ & $4(1)$ & \\
\hline \multirow{5}{*}{$\begin{array}{l}\text { What is your } \\
\text { perception of level } \\
\text { of risk of } \\
\text { contracting } \\
\text { COVID-19 } \\
\text { infection? }\end{array}$} & Most risk & $196(50.1)$ & $171(42)$ & 0.019 \\
\hline & High risk & $131(33.5)$ & $163(38.9)$ & \\
\hline & Moderate risk & 31 (7.9) & $55(13.1)$ & \\
\hline & $\begin{array}{l}\text { Risk similar to that of } \\
\text { contracting the } \\
\text { common cold }\end{array}$ & $21(5.4)$ & $14(3.3)$ & \\
\hline & No risk & $12(3.1)$ & $11(2.6)$ & \\
\hline \multirow{3}{*}{$\begin{array}{l}\text { Can eating garlic } \\
\text { prevent infection } \\
\text { with the } \\
\text { coronavirus? }\end{array}$} & Yes & 85 (21.7) & $82(19.6)$ & 0.663 \\
\hline & No & $124(31.7)$ & $143(34.1)$ & \\
\hline & Not sure & $182(46.5)$ & $194(46.3)$ & \\
\hline \multirow{3}{*}{$\begin{array}{l}\text { Will warm weather } \\
\text { stop the outbreak } \\
\text { of COVID-19? }\end{array}$} & Yes & 195 (49.9) & $176(42)$ & 0.017 \\
\hline & No & $98(25.1)$ & $101(24.1)$ & \\
\hline & Not sure & $98(25.1)$ & 142 (33.9) & \\
\hline \multirow{4}{*}{$\begin{array}{l}\text { How do you } \\
\text { normally treat } \\
\text { yourself when you } \\
\text { get a cough or } \\
\text { fever? }\end{array}$} & $\begin{array}{l}\text { Self-medication like } \\
\text { Antibiotics }\end{array}$ & $150(38.4)$ & $155(37)$ & 0.410 \\
\hline & Consult Doctor & $162(41.4)$ & $169(40.3)$ & \\
\hline & Google my symptoms & $3(0.8)$ & $9(2.1)$ & \\
\hline & $\begin{array}{l}\text { Local remedies like } \\
\text { steam }\end{array}$ & $76(19.4)$ & $86(20.5)$ & \\
\hline
\end{tabular}

Table IV: Comparison of COVID-19 practices between pharmacy and non-pharmacy students

\begin{tabular}{llccc}
\hline Variables & Response & $\begin{array}{c}\text { Pharmacy } \\
\text { students } \\
\text { N (\%) }\end{array}$ & $\begin{array}{c}\text { Non- } \\
\text { Pharmacy } \\
\text { Students } \\
\text { N (\%) }\end{array}$ & $\begin{array}{c}p \text { - } \\
\text { value }\end{array}$ \\
\hline $\begin{array}{llccc}\text { What is your daily } \\
\text { surgical mask use? }\end{array}$ & Never & $98(25.1)$ & $98(23.4)$ & 0.006 \\
& Sometimes & $252(64.5)$ & $244(58.2)$ & \\
& $\begin{array}{l}\text { Every day at } \\
\text { all times }\end{array}$ & $41(10.5)$ & $77(18.4)$ & \\
\hline $\begin{array}{l}\text { What is your } \\
\text { frequency of washing } \\
\text { hands per day }\end{array}$ & Nil & $2(0.5)$ & $7(1.7)$ & 0.237 \\
& 2-4 times & $66(16.9)$ & $77(18.4)$ & \\
& $>4$ times & $323(82.6)$ & $335(80)$ & \\
\hline $\begin{array}{l}\text { What is your } \\
\text { frequency of using } \\
\text { soap for hand washing } \\
\text { per day }\end{array}$ & Nil & $2(0.5)$ & $3(0.7)$ & 0.411 \\
& Sometimes & $69(17.6)$ & $60(14.3)$ & \\
\hline
\end{tabular}

The Internet or social media, healthcare professionals, and others were common information sources. The knowledge scores between married and unmarried students were significantly different $(p<0.041)$. The difference between the knowledge score was nonsignificant between males and females ( $p=0.081)$, PS and NPS ( $p=0.379)$, and according to age categories and family members (Table I). The comparison of COVID-19 knowledge for specific questions showed that NPS had significantly better knowledge about the source $(p<$ 0.001), while PS had better knowledge regarding COVID-19 treatment $(p=0.01)$ (Table II). The PS's perception of the dangerousness and risk of contracting COVID-19 infection was better than NPS's perception ( $p=$ $0.026 ; p=0.019$, respectively). More PS believed that

Table V: Linear analysis with knowledge score and logistic regression analysis of attitude with different variables

\begin{tabular}{|c|c|c|c|c|c|c|c|c|}
\hline \multirow[t]{3}{*}{ Variables } & \multicolumn{4}{|c|}{ Knowledge score } & \multicolumn{4}{|c|}{ Attitude } \\
\hline & \multicolumn{2}{|c|}{ b } & \multicolumn{2}{|c|}{ 95.0\% Confidence Interval for B } & \multirow[b]{2}{*}{$\operatorname{Exp}(B)$} & \multirow[b]{2}{*}{ p-value } & \multicolumn{2}{|c|}{ 95.0\% Confidence Interval for B } \\
\hline & B & p-value & Lower Bound & Upper bound & & & Lower bound & Upper bound \\
\hline Female & -0.371 & 0.043 & -0.730 & -0.012 & 0.529 & 0.003 & 0.348 & 0.806 \\
\hline Age $21-25$ years & 0.133 & 0.311 & -0.124 & 0.389 & 1.243 & 0.142 & 0.930 & 1.661 \\
\hline Age $>25$ years & 0.595 & 0.197 & -0.309 & 1.499 & 0.616 & 0.361 & 0.218 & 1.743 \\
\hline Married & 0.078 & 0.819 & -0.589 & 0.744 & 0.760 & 0.475 & 0.358 & 1.613 \\
\hline Pharmacy students & 0.104 & 0.428 & -0.153 & 0.360 & 1.068 & 0.654 & 0.800 & 1.427 \\
\hline Family members 4-6 & -0.006 & 0.983 & -0.516 & 0.505 & 0.869 & 0.633 & 0.488 & 1.547 \\
\hline Family members $>7$ & -0.174 & 0.523 & -0.710 & 0.361 & 0.961 & 0.897 & 0.525 & 1.759 \\
\hline
\end{tabular}


warm weather would stop the outbreak $(p<0.017)$ (Table III). There was no significant difference observed between PS's and NPS's attitudes ( $p=0.848$ ) (not shown in Table).

The use of masks was better among PS than NPS $(p=0.006)$, and no difference was found in the frequency of hand-washing and frequency of use of soap (table IV). Linear regression analysis revealed that the knowledge score was negatively associated with the female gender. In logistic regression analysis, the odds ratio ( $O R=0.52)$ indicates that females were $48 \%$ less likely to have a positive attitude (Table V).

\section{Discussion}

This study could not observe any significant difference in the knowledge score between males and females, PS and NPS, age categories, and according to the number of family members.

All students were knowledgeable about the disease. Similar to the authors' results, studies conducted on undergraduate medical students showed that they also had good knowledge regarding COVID-19 (Agarwal et al., 2020; Maheshwari et al., 2020). The authors could not find any study in which PS's knowledge was compared with other university students. However, studies are available on similar topics related to hospital pharmacists' perceptions (Kara, Demirkan \& Ünal, 2020; Karasneh et al., 2020; Zeenny et al., 2020).

Both PS and NPS had good knowledge of the spread of COVID-19, the increased risk associated with comorbid conditions, and reinfection with the disease. Both PS and NPS agreed that health education could prevent the further spread of the disease. However, it was apparent that they had poor knowledge regarding the spread of COVID-19 through food, safety levels of lab testing for COVID-19, and COVID-19 survival on porous and nonporous surfaces. This is important for policymakers because, at this point, when the lockdown is lifted and restrictions are eased for everyone, proper knowledge, especially at the university level, is very important.

Students' common information sources were the Internet and social media, followed by television and healthcare providers. The least utilised source was the newspaper and social community services. Similar to the authors' results, another study conducted in Italy showed that television, followed by social media, is the most common source of information for students (Dilucca \& Souli, 2020). A Turkish study reported that television and newspapers,
Internet, and social media were the common information sources among pharmacists (Kara, Demirkan \& Ünal, 2020). Although social media provided an important source of transferring information, all information should be monitored carefully for false information by the authorities involved and through cross-sectional collaboration (Gao et al., 2020).

Pharmacists are pivotal players in any healthcare system and their accurate knowledge, attitudes, and practices are necessary for combating any disease (Zeenny et al., 2020). Therefore, it is important to educate PS on dealing with this type of pandemic in the future (Cadogan \& Hughes, 2020).

Although most of the students showed a positive attitude towards this pandemic, the authors could not find any significant difference between PS's and NPS's attitudes. While comparing the preparedness and practice, the authors found that the use of masks was significantly better in PS than NPS. The wearing of a mask is essential, as COVID-19 is a droplet infection, and many health organisations, such as WHO and Centres for Disease Control and Prevention $\mathrm{CDC}$, have recommended wearing a mask, especially while going outside and in public places where social distancing is challenging to maintain (WHO Health Emergencies Programme, 2020). Howard et al. (2020) indicated that face mask use lessens the transmissibility per contact in both research centers and clinical settings by diminishing contaminated droplets transmission. They also concluded that wearing a mask is best for halting the infection spread where transmission rates are high.

This study's results are comparable to several studies conducted among pharmacists. Karasneh et al. (2020) reported good basic knowledge and risk perception of COVID-19 among Jordanian pharmacists (Karasneh et al., 2020). A Lebanese study demonstrated an appropriate level of knowledge and good practice towards COVID-19 among the Lebanese hospitals' pharmacists (Zeenny et al., 2020). Turkish pharmacists had good knowledge and perception about the route of transmission and risk groups for COVID-19 infection. They were washing hands frequently and avoiding interaction with infected people (Kara, Demirkan \& Ünal, 2020).

Linear regression analysis showed that the female gender is negatively associated with the knowledge score. In logistic regression analysis, the odds ratio indicated that females were less likely to have positive attitudes than males. In contrast to the authors' results, a study in China showed a negative association of knowledge with the 
male gender (Zhong et al., 2020). A study in Saudi Arabia found a positive attitude among females (Baig et al., 2020). The strength of the present study lies with the fact that it was conducted while the lockdown restrictions were being strictly followed in Pakistan, and COVID-19 cases were increasing exponentially. Therefore, it was a good time to find out about students' perceptions regarding COVID-19.

This study did not observe any significant difference in the knowledge score between males and females, and PS and NPS. However, PS's knowledge in some areas was better, and in few areas worse, than that of NPS. The authors do not have any specific explanation for this difference in their knowledge.

\section{Limitations}

The current study had some limitations, such as the online questionnaire survey, which could not be accessed by students who did not use social media. It is also possible that students might have chosen the expected correct answer rather than what they are practicing at home.

\section{Conclusion}

This study showed that pharmacy students in the Punjab province are well-informed, optimistic, and prepared for COVID-19. However, there is still confusion about the disease that needs to be resolved.

\section{References}

Agarwal, V., Gupta, L., Davalbhakta, S., Misra, D., Agarwal, V., \& Goel, A. (2020). Undergraduate medical students in India are underprepared to be the young-taskforce against Covid-19 amid prevalent fears. medRxiv. https://doi.org/10.1101/2020.04.11. $\underline{2006133}$

Ahmad, T., Haroon, Baig, M., \& Hui, J. (2020). Coronavirus Disease 2019 (COVID-19) Pandemic and economic impact. Pakistan Journal of Medical Sciences, 36(COVID19-S4), 73-78. https://doi. org/10.12669/pjms.36.COVID19-S4.2638

Akram, M.A. (2020). COVID-19 Pandemic and Government Policies to Control its Situation in Pakistan. Acta Scientific Microbiology, 3, 164-170. https://doi.org/10.31080/ASMI.2020.03.0626

Baig, M., Jameel, T., Alzahrani, S.H., Mirza, A.A., Gazzaz, Z.J., Ahmad, T., \& Almurashi, S.H. (2020). Predictors of misconceptions, knowledge, attitudes, and practices of COVID-19 pandemic among a sample of Saudi population and its impact: a cross-sectional study. medRxiv. https://doi.org/10.1101/2020.05.22.20110627
Cadogan, C.A., \& Hughes, C.M. (2020). On the frontline against COVID-19: Community pharmacists' contribution during a public health crisis. Research in Social and Administrative Pharmacy. https://doi.org/10.1016/i.sapharm.2020.03.015

Chandasiri, O. (2020). The COVID-19: Impact on Education. Journal of Asian and African Social Science and Humanities, 6(2), 38-42. Available: https://www.aarcentre.com/ojs3/index.php/aarcentre/ article/view/207

Cohen, J. (2020). Vaccine designers take first shots at COVID-19. Science, 368(6486), 14-16. https://doi.org/10.1126/science.368. $\underline{6486.14}$

Dilucca, M., \& Souli, D. (2020). Knowledge, attitude and practice of secondary school students toward COVID-19 epidemic in Italy: a cross selectional study. bioRxiv. https://doi.org/10.1101/2020. $\underline{05.08 .084236}$

Gao, J., Zheng, P., Jia, Y., Chen, H., Mao, Y., Chen, S., Wang, Y., Fu, H., \& Dai, J. (2020). Mental health problems and social media exposure during COVID-19 outbreak. PLOS One, 15(4), e0231924. https://doi.org/10.1371/journal.pone.0231924

Ghadyani, M., Hussain, H., Odeh, W., \& Wood, P. (2020). Responses to the COVID-19 Pandemic in Syria, Iran and Pakistan. Abdou Filali-Ansary Occasional Paper Series. Book 2. Available at: https://ecommons.aku.edu/uk ismc series ops/2

Howard, J., Huang, A., Li, Z., Tufekci, Z., Zdimal, V., van der Westhuizen, H.-M., von Delft, A., Price, A., Fridman, L., Tang, L.-H., Tang, V., Watson, G.L., Bax, C.E., Shaikh, R., Questier, F., Hernandez, D., Chu, L.F. Ramirez, C. M., \& Rimoin, A.W. (2020). Face masks against COVID-19: an evidence review. Preprints 2020. https://doi.org/10.20944/preprints202004.0203.v1

ICG [International Crisis Group]. (2020). Pakistan's COVID-19 crisis. Available at: https://www.crisisgroup.org/asia/south-asia/ pakistan/b162-pakistans-covid-19-crisis

Kara, E., Demirkan, K., \& Ünal, S. (2020). Knowledge and attitudes among hospital pharmacists about COVID-19. Turkish Journal of Pharmaceutical Sciences, 17(3), 242-248. https://doi.org/10.4274/ tips.galenos.2020.72325

Karasneh, R., Al-Azzam, S., Muflih, S., Soudah, O., Hawamdeh, S., \& Khader, Y. (2020). Media's effect on shaping knowledge, awareness risk perceptions and communication practices of pandemic COVID-19 among pharmacists. Research in Social and Administrative Pharmacy. https://doi.org/10.1016/i.sapharm. $\underline{2020.04 .027}$

Leung, K., Wu, J.T., Liu, D., \& Leung, G.M. (2020). First-wave COVID-19 transmissibility and severity in China outside Hubei after control measures, and second-wave scenario planning: a modelling impact assessment. The Lancet, 395, 1382-93. https://doi.org/10.1016/S0140-6736(20)30746-7

Lurie, N., Saville, M., Hatchett, R., \& Halton, J. (2020). Developing Covid-19 vaccines at pandemic speed. New England Journal of Medicine, 382(21), 1969-1973. https://doi.org/10.1056/NEJMp $\underline{2005630}$

Maheshwari, S., Gupta, P.K., Sinha, R., \& Rawat, P. (2020). Knowledge, attitude, and practice towards coronavirus disease 2019 (COVID-19) among medical students: A cross-sectional study. Journal of Acute Disease, 9(3), 100-104. https://doi.org/ $\underline{10.4103 / 2221-6189.283886}$ 
Mohamad, E., \& Azlan, A.A. (2020). COVID-19 and communication planning for health emergencies. Jurnal Komunikasi: Malaysian Journal of Communication, 36(1), 1-2

Nantwi W.K., \& Boateng B. (2020). COVID-19 and education in Ghana: a tale of chaos and calm. African Journal of Emerging Issues, 2(5), 41-52

Government of Pakistan. (2020). Travelers entering Pakistan. Available at: http://covid.gov.pk/intl travellers/current_policies

Sahu, P. (2020). Closure of Universities Due to Coronavirus Disease 2019 (COVID-19): Impact on Education and Mental Health of Students and Academic Staff. Cureus, 12(4), e7541. https://doi.org.10.7759/cureus.7541

Shechter, A., Diaz, F., Moise, N., Anstey, D.E., Ye, S., Agarwal, S., Birk, J.L., Brodie, D., Canone, D.E., Chang, B., Claassen, J., et al. (2020). Psychological distress, coping behaviors, and preferences for support among New York healthcare workers during the COVID-19 pandemic. General Hospital Psychiatry, 66, 1-8. https://doi.org.10.1016/i.genhosppsych.2020.06.007

Shoenfeld, Y. (2020). Corona (COVID-19) time musings: our involvement in COVID-19 pathogenesis, diagnosis, treatment and vaccine planning. Autoimmunity Reviews, 19(6), 102538. https://doi.org.10.1016/i.autrev.2020.102538

Srichan P., Apidechkul T., Tamornpark R., Yeemard, F., Khunthason, S., Kitchanapaiboon, S., Wongnuch, P., Wongphaet, A., \& Upala, P. (2020). Knowledge, attitude and preparedness to respond to the 2019 novel Coronavirus (COVID-19) among the bordered population of northern Thailand in the early period of the outbreak: a cross-sectional study. SSRN. http://dx.doi.org/ $\underline{10.2139 / \text { ssrn. } 3546046}$

WHO Health Emergencies Programme [WHE]. (2020). Coronavirus disease 2019 (COVID-19). Available at: https://www.who.int/ docs/default-source/coronaviruse/corrigendum-to-ig-2020-4-ipcmasks-2020-06-05-pp-15-16-2020-06-06-e.pdf?sfursn=c5992b89 2

WHO [World Health Organization]. (2020a). Coronavirus disease (COVID-19). Situation Report 192. Available at: https://www.who. int/docs/default-source/coronaviruse/situation-reports/20200730 -covid-19-sitrep-192.pdf?sfvrsn=5e52901f 8

WHO [World Health Organization]. (2020b). What do we know about COVID-19 transmission? The latest on transmission \& the current global situation. Coronavirus update 33. Available at: https://www.who.int/docs/default-source/coronaviruse/risk-com ms-updates/update-33-trasmission.pdf?sfursn=9b1b10aa 2

Zeenny, R.M., Ramia, E., Akiki, Y., Hallit, S., \& Salameh, P. (2020). Assessing knowledge, attitude, practice, and preparedness of hospital pharmacists in Lebanon towards COVID-19 pandemic: a cross-sectional study. Journal of Pharmaceutical Policy and Practice, 13(1), 1-12. https://doi.org/10.1186/s40545-020-00266-8

Zhong, B.L., Luo, W., Li, H.M., Zhang, Q.Q., Liu, X.G., Li, W.T., \& Li, Y. (2020). Knowledge, attitudes, and practices towards COVID-19 among Chinese residents during the rapid rise period of the COVID-19 outbreak: a quick online cross-sectional survey. International Journal of Biological Sciences, 16(10), 1745-1752. https://doi.org/10.7150/ijbs.45221 